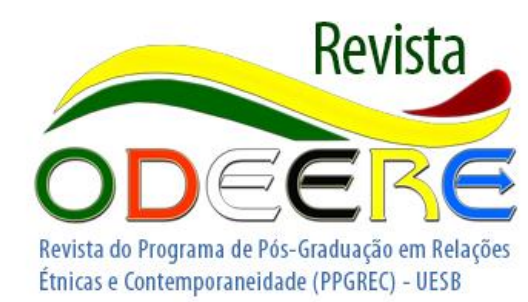

\title{
Geertz e os usos da diversidade: uma perspectiva pós-estruturalista
}

\author{
Alexandre de Oliveira Fernandes \\ Instituto Federal de Tecnologia \\ (IFBA/Porto Seguro-BA) \\ alexandre.pro@gmail.com
}

Resumo: Este ensaio coloca em questão os "usos da diversidade" em uma perspectiva pós-estruturalista. Para tanto, faz surgir um discurso agonístico e ambivalente dos estudos antropológicos de Clifford Geertz. Ali, dá-se a ver um saber e uma clivagem abertos à Filosofia e à Ética comprometidas com o poder decolonial.

Palavras-chave: Diversidade; Antropologia; Pós-estruturalismo

\section{Abstract}

This essay discusses the "uses of diversity" in a poststructuralist perspective. For this purpose, it raises an agonistic and ambivalent discourse from the anthropological studies of Clifford Geertz. Them, there is a knowledge and a cleavage opened to Philosophy and Ethics committed to a decolonial power.

Key-words: Diversity; Anthropology; Poststructuralism 
É no encontro incômodo de subjetividades variantes na sua própria sociedade que o antropólogo define seu lugar.

Clifford Geertz

\section{Envolver-se na diferença: o encontro, o entre-lugar, a fissura}

Trazemos à reflexão um problema enunciado por Clifford Geertz, qual seja, "É no encontro incômodo de subjetividades variantes na sua própria sociedade que o antropólogo define seu lugar" $^{1}$. E o fazemos porque esta é a chave do que buscamos aprofundar, a saber, os usos da diversidade frente a um crescente e perigoso etnocentrismo, com vistas a fortalecer nossa "imaginação" para aprender o que está bem diante dos nossos olhos: as pessoas são dessemelhantes e a diferença é a tônica.

Sendo imprescindível levarmo-nos em conta - como pessoas que vivem em sociedade -, devemos aprender - e isto só aparentemente é óbvio - que ninguém está imune à diferença mesmo em seu próprio convívio, na sua cidade, em sua comunidade, no seu país, em sua religião, em seu gabinete. Com Geertz se compreende que até os antropólogos podem ser estudados como uma aldeia, sujeitos a regras, padrões, costumes, os quais demandam dessemelhanças e assimetrias. Ou seja, mesmo no ambiente intelectual, não há que se tratar de unanimidade, pelo contrário, é a diferença que sempre dá o tom.

Tal reconhecimento é uma obra político-teórica que surge com o movimento da descolonização e se reafirma num pensamento decolonial, ao postular a emergência do sujeito pós-colonial, o qual se insurge como sujeito do conhecimento, protagonista de si e de sua história ${ }^{2}$. Por um lado, abre caminho para um olhar sob a perspectiva deste sujeito - do Sul para o Norte, do subalternizado para o colonizador, da periferia para o centro -, por outro lado, nos

\footnotetext{
${ }^{1}$ Esta citação - colocada por nós em epígrafe, mas não somente -, faz parte de resumo do texto de Geertz, "Os usos da diversidade", publicado na revista Horizontes Antropológicos. Tal resumo não se encontra no livro "Nova Luz sobre a Antropologia" - no qual também se pode ler o mesmo texto: "Os usos da diversidade" -, haja vista ser ele uma coletânea de ensaios. Interessante como um texto se dá à apropriação, ao jogo e ao movimento da leitura e do suporte, ora é parte de resumo, ora é epígrafe, ora pode ser citação, ou mesmo um mote para se começar um texto que trata da diversidade. $O$ texto em uma revista eletrônica ganha face de artigo, já em um livro editado torna-se parte de coletânea de ensaios, donde se pode inferir que nenhum texto tem sentido em si mesmo, senão no contexto em ação. GEERTZ, Clifford. Os usos da diversidade. Horizontes Antropológicos, Porto Alegre, ano 5, n. 10, p. 13-34, maio 1999.

${ }^{2}$ Sobre estas perspectivas destaco estudos de Catherine Walsh e Walter Mignolo. Cf. WALSH, Catherine. Pensamiento crítico y matriz (de)colonial. Reflexiones latino-americanas. Quito: Ediciones Abya-yala, 2005; MIGNOLO, Walter. Histórias locais/Projetos globais. Colonialidade, saberes subalternos e pensamento liminar. Belo Horizonte: Ed. UFMG, 2003.
}

Odeere: revista do programa de pós-graduação em Relações Étnicas e Contemporaneidade - UESB. Ano 1, número 1, volume 1, Janeiro - Junho de 2016. 
convoca a analisar as sociedades ocidentais e colonizadoras, evidenciando os padrões de discriminação e violência que nelas vigoram, ou seja, olhando dentro delas mesmas.

Importante também destacar que, empregamos os termos "descolonização" e "decolonial" não no sentido cronológico de posterioridade a um processo de colonização, mas como um conceito que problematiza discursos que camuflam relações de dominação, hierarquias, poder e essencialismos. Por isso, tal perspectiva coloca em foco as estruturas de poder e de saber, interessando-se pela geopolítica do conhecimento, problematizando a produção, a veiculação, a contextualização dos saberes e o domínio epistemológico.

A descolonização não se remete apenas à desocupação de territórios, mas à independência cultural, econômica e, sobremodo, à independência das mentalidades, o que privilegia outras formas de ser e de existir, diversas daquelas impostas pelo colonizador, buscando deslocar as relações de poder. Ou seja, prima por ressignificar e dissolver estereótipos e preconceitos, fortalecendo a auto capacidade de ação dos grupos marginalizados. Sua ação interroga o paradigma coercitivo e genocida que sustentou a própria invenção da modernidade. Isto abre o campo de pensamento para a possibilidade de reconstruir novas relações e formas díspares de racionalidade.

Atenta, a "antropologia do sensível" de Geertz promove um "corpo a corpo" com os textos antropológicos, com o trabalho de campo e conosco mesmo, fugindo de modelos simplistas e dicotômicos, numa maneira complexa e especial de reagir a um etnocentrismo repressivo das diferenças. Trata-se de uma sensibilidade que inverte o olhar antropológico, do macro para o micro, da Europa para as margens, do outro distante para o outro que mora em mim e que está aqui, bem debaixo dos meus olhos ${ }^{3}$. Não se trata de uma antropologia que investiga exotismos de fora com ares de superioridade e assimetria. Todos somos nativos, independentemente de onde estejamos, no além-mar ou no fim do corredor em um gabinete. As distâncias cultural e geográfica dão lugar a uma etnografia que fora trazida de volta para casa e para a qual, interessam mini narrativas. O narrador vira parte do estudo e as histórias, longe de um cabedal linear, navegam por uma nebulosa de histórias, uma profusão de biografias em conexão e contraste. Destas histórias saltam o sensível, a ensinar que, por um lado, devemos compreender que estamos numa

\footnotetext{
${ }^{3}$ Escreveu Silviano Santigo que a Antropologia, incialmente um discurso científico que nascera para fortalecer o domínio europeu, teve papel importante ao operar um "descentramento" no pensamento ocidental, haja vista que trouxe à luz outras arenas de verdades e referências, colocando em xeque a excelência das hierarquias e da cultura dos conquistadores. SANTIAGO, Silviano. Vale quanto pesa: ensaios sobre questões político-culturais. Rio de Janeiro: Paz e Terra, 1982, p. 17.
}

Odeere: revista do programa de pós-graduação em Relações Étnicas e Contemporaneidade - UESB. Ano 1, número 1, volume 1, Janeiro - Junho de 2016. 
aldeia global de culturas múltiplas e ricas, por outro lado, que há uma multivocidade do ser, a qual implica serem as culturas múltiplas nelas mesmas. O "encontro incômodo" é, pois, inevitável".

Sem obscurecer as dessemelhanças e as assimetrias "entre" mim e os que pensam diferentemente de mim, ao contrário, o antropólogo norte-americano, entende que é na clivagem e na diferença "entre" o que penso e aqueles que agem diferentemente - mesmo fazendo parte do meu grupo -, que o self se apresenta e revela suas singularidades ${ }^{5}$.

Nesse "entre" dá-se a ver uma fissura, um embate entre culturas e entre culturas dentro de uma mesma cultura, possibilitando narrativas e enredos que falam de nós mesmos, que nos representam "e a todos os outros como jogados no meio de um mundo repleto de estranhezas irremovíveis, que não temos como evitar" ${ }^{6}$.

Importa estar atento às "narrativas" que surgem dos encontros com o outro, não como enunciados em si, mas como signo de um auto desvelamento: elas falam mais de nós mesmos do que dos outros; aproximando-nos do modo como produzem sujeitos e subjetividades, aprendendo como as histórias interpelam os sujeitos e posicionam os espectadores.

De todo modo, evitaremos "definir" um lugar para o antropólogo, seja porque este não é o objetivo do presente ensaio, seja porque entendemos que uma definição não resolve nada. É mais produtivo deixar "o lugar do antropólogo" a encargo do poder da "metáfora" que, sem cessar desloca - tira do lócus - todo sentido acabado e a referência estável.

"Definir" é tentar pôr fim à fluidez, à flexibilidade, à natureza incontrolável do contexto, do significado por vir. Ao recusarmos a definição, acenamos para o rasto incessante de "uma experiência da diferença temporal de um passado sem presente passado ou de um porvir que não seja um futuro presente" ${ }^{\prime 7}$. Adiemos o sentido, porque o significante (que definiria algo a alguém) não se relaciona diretamente a um significado pleno senão a mais significantes que em contraste e diferença produzem sentidos flutuantes, marcados constantemente pela presença e ausência do sentido.

\footnotetext{
${ }^{4}$ Concordamos com Femi Ojo Ade, para quem cultura é "o modo pelo qual as pessoas vivem, a totalidade de suas crenças, códigos de conduta, técnicas, todos os elementos necessários à existência em uma estrutura social. E com Gilberto Velho para quem, há cultura quando existem "símbolos compartilhados, linguagem básica comum, gramaticalidade no processo de interação e negociação da realidade, expectativas e desempenhos de papéis congruentes". Cf. OJO-ADE, Femi. Negro: Raça e Cultura. Salvador, BA, Ed. UFBA, 2007, p.5; VELHO, Gilberto. Projeto e Metamorfose: Antropologia das Sociedades Complexas, Rio de Janeiro, Jorge Zahar, 1994, p. 17.

${ }^{5}$ GEERTZ, Clifford. Nova luz sobre a antropologia. Tradução: Vera Ribeiro. Rio de Janeiro: Jorge Zahar, 2001, p. 76.

${ }^{6}$ Ibid., p. 85.

${ }^{7}$ DERRIDA, Jacques. Papel-máquina. Tradução: Evando Nascimento. São Paulo: Estação Liberdade, 2004, p. 339.
}

Odeere: revista do programa de pós-graduação em Relações Étnicas e Contemporaneidade - UESB. Ano 1, número 1, volume 1, Janeiro - Junho de 2016. 
O "lugar" do antropólogo, indefinido, escancara algo que se dá a ver e se esconde, apresenta-se e não está mais. O reino do significante se impõe, sendo que jamais se chega a um significado final que não aponte para outro significante e em seguida, mais significantes e significados.

Já que nenhum código pode ser decifrado de maneira fria e distante, ficam à deriva pretensões a verdades absolutas. Estas são afetadas pelo movimento da diferença, que é vivo, panorâmico, repleto de colagens, afastamentos, aproximações e continuuns. O movimento da diferença perfaz uma Ética de abertura para o outro, haja vista que nada existe que não seja em relação, tudo ocorrendo no âmbito de uma estrutura de referências e num processo de disseminação.

O lugar do antropólogo abre-se à alteridade e, ao invés de uma oposição simplista bem/mal; Ocidental/Oriental; antropólogo/historiador; cristão ortodoxo/protestante luterano; morador de Dubai/indígena; civilizado/bárbaro -, temos o "encontro" incômodo de subjetividades variantes, uma relação agonística que nunca se resolve e, no entanto, não para de agonizar.

Para ilustrar nossas afirmações, um vídeo tem circulado pelas redes sociais acerca da manifestação de alunos que interromperam a aula de probabilidade de um professor do Instituto de Matemática, Estatística e Computação Científica da Universidade de Campinas - Unicamp, impedindo-o de lecionar ${ }^{8}$.

À medida que escrevia no quadro, alunos batucavam e apagavam as fórmulas matemáticas. Ora, tomando-se partido, é fácil tratar os alunos que fazem parte do movimento "Ocupa Unicamp" como invasores e ficarmos com uma imagem maniqueísta. Mas, efetivamente, o que se dá a ler deste "encontro" incômodo entre um professor que se opõe à greve e educandos a ela favoráveis é um embate em que a condição e o condicionado, numa mútua implicação e contínua transformação, tornam o encontro complexo e nada se apazigua - como numa escolha entre pares de opostos ou condições gerais -, de um lado, caos e confusão, de outro a ordem e a civilidade. O "bárbaro" está de um lado e de outro da linha divisória, seja ele algoz ou vítima, professor ou estudante.

Desdobramentos do vídeo em questão já dão a ver nas redes sociais, um movimento de apoio ao professor, por um lado, e por outro, de comentários homofóbicos e agressões aos alunos, especialmente a um deles, que estuda no Instituto de Geociências da Unicamp e que

\footnotetext{
${ }^{8}$ http://g1.globo.com/sp/campinas-regiao/noticia/2016/06/professor-tem-aula-interrompida-na-unicamp-e-reclamade-inseguranca.html
}

Odeere: revista do programa de pós-graduação em Relações Étnicas e Contemporaneidade - UESB. Ano 1, número 1, volume 1, Janeiro - Junho de 2016. 
aparece nas imagens apagando a lousa. A página do DCE Unicamp no Facebook ${ }^{9}$ relatou "uma onda de mensagens de ódio extremamente racistas, homofóbicas, agressivas e inclusive ameaças de violência e morte".

Não há como fugir da diferença irredutível e de seu mal estar. Disso sabendo, Geertz não produz uma leitura estrutural acerca do que seja a antropologia ou o "lugar" do antropólogo, ao contrário, sua "definição" abre-se à clivagem, sendo ela uma "não definição". Ele busca um "entre" que vacila na agonia do sentido e desloca nosso olhar para uma Ética e uma Filosofia que postergam a presença definida e transparente. Desvia nosso olhar para um mundo de diversidades cuja bricolagem e justaposição deveriam retroceder o etnocentrismo e dar visibilidade à diversidade de doutrinas e à pluralidade de concepções conflituosas.

Geertz se nos provoca uma "estranheza", uma alteridade que não se resolve em oposições binárias - mocinho/bandido -, mas aponta para complicações de um terreno pantanoso e disjuntivo, repleto de armadilhas e passagens intermináveis, constrangendo cada uma das fronteiras de um "eu/ele" bem marcado e resolvido.

Chama nossa atenção para a presença do outro - entendido de modo amplo, inclusive com suas relações históricas -, que retroalimenta o pensamento e muda uma paisagem que se queria estável e límpida. "Há turcos na Baviera, filipinos no Kuwait e russos nas praias de Brighton ${ }^{10 ",}$ assim como percebemos no Arraial d'Ajuda, distrito de Porto Seguro, onde moramos, baianos do Recôncavo e da Costa do Cacau, ingleses, alemães, franceses, uruguaios, argentinos, fazendo desfilar um "fluxo incrível de mentalidades conflitantes ${ }^{11 "}$ - e não se há que falar apenas em turistas, mas moradores que se fixam e, no entanto, já não estão mais.

O contato com pessoas com tipos de crenças diversas é signo do mundo sem fronteiras, híbrido e sazonal, para o qual trazemos nossas raízes, desejos e sonhos, viajando conosco de um canto a outro. A mobilidade territorial implica em uma multiplicação e uma efervescência de identidades culturais, num modo legítimo de ser ao mesmo tempo, cidadão de muitas pátrias e de nenhuma. Esta mobilidade identitária/espacial, favorece as potencialidades do entre-lugar intersticial que define e divide sujeitos e desejos antagônicos.

\footnotetext{
${ }^{9}$ Mesma página em que o leitor pode ver-se convidado a participar do X Colóquio Internacional Michel Foucault, que acontecerá ainda este ano na Unicamp, organizado por Margareth Rago e Silvio Gallo, sob o título intrigante e apropriado, qual seja, "É inútil revoltar-se?" Cf. http://www.ifch.unicamp.br/ifch/noticias-eventos/programahistoria/x-coloquio-internacional-michel-foucault-inutil-revoltar-se

${ }^{10}$ GEERTZ, Clifford. Nova luz sobre a antropologia. Tradução: Vera Ribeiro. Rio de Janeiro: Jorge Zahar, 2001, p. 158.

${ }^{11}$ Ibid., p. 221.
}

Odeere: revista do programa de pós-graduação em Relações Étnicas e Contemporaneidade - UESB. Ano 1, número 1, volume 1, Janeiro - Junho de 2016. 
Por que falar em "lugar" do antropólogo como algo que se define, então? Não estamos defendendo um relativismo, um laissez faire em que tudo pode ocorrer, o qual, certamente, deturparia os estudos de Geertz. Seus estudos não permitem que se relativize ao máximo a realidade. Por outro lado, sabidamente, ele põe em questão certa reação não justificada contra o relativismo cultural, por isso se posiciona mais como um anti anti-relativista. Sua escrita coloca sob suspeita as saídas rápidas e as dicotomias simplistas, que de modo esquizofrênico e tratando a cultura como algo estável, atacam o relativismo. Não à toa, ensina-nos a evitar pensamentos pasteurizados: "examinar dragões, não domesticá-los ou abominá-los, nem afogá-los em barris de teoria, é tudo que consiste a antropologia"12.

Se existisse um "lugar" para o antropólogo, este se encontraria em profundo e permanente processo de redefinição, à força de uma deriva e de uma espera - operação mais estimulante, mais potente do que todo conteúdo, toda tese e todo sentido que se querem certos e transparentes. Por outro lado, se existissem "a" definição e "o" lugar, estes permaneceriam absortos no abismo da linguagem e, caso de lá retornassem, viriam até nós por meio de arroubos e sobre entradas do sentido.

Os efeitos de construção de entendimentos, os jogos da linguagem e transportes de sentido (lembremos que "metáfora" se remete à "mudança de sentido"), os quais fazem parte da construção de entendimento do texto - que se dá em fluxo, em devir e nunca está completo -, não devem ser ignorados, à medida que nos lancemos ao "encontro" de "subjetividades variantes".

A definição, quando aceita por alguém ou algo, como um paradigma ou uma doxa ${ }^{13}$, representa e apresenta um "jogo da verdade", cujo intuito não é mascarar a verdade, mas o próprio jogo ${ }^{14}$ que produz os sentidos. O que esse jogo faz desaparecer como num passe de mágica é a construção, o edifício no qual o sentido se assenta. Assim, apagado o jogo, "a" verdade, transparente e unívoca, parece bailar no ar como se fosse um sozinho no mundo.

Ao não nos coadunarmos com tal postulação para "a" "verdade", haja vista que não há linguagem pura e imanente na qual sentido e letra possam descansar indissociáveis, interessamonos por rasurar o jogo, implodindo o sistema que faz significar a verdade. Delatamos o "lugar" do

\footnotetext{
12 Ibid., p. 65.

${ }^{13}$ A doxa é o oposto do paradoxo. Este mantem a aporia, o beco sem saída, a tensão e a incerteza, aquele é uma opinião corrente, grudenta e insuportável, imóvel e cheia de certezas e estabilidades. BARTHES, Roland. Roland Barthes por Roland Barthes. Tradução: Leyla Perrone-Moisés. São Paulo: Estação Liberdade, 2003, p. 85.

14 Ibid., p. 159.
}

Odeere: revista do programa de pós-graduação em Relações Étnicas e Contemporaneidade - UESB. Ano 1, número 1, volume 1, Janeiro - Junho de 2016. 
antropólogo, como não espacial, material, localizável ou centrado: é filosófico ${ }^{15}$. E o fazemos para dar margem a algo mais interessante, qual seja, o "encontro", o "entre-lugar", a fissura, a ranhura e o embate das dessemelhanças constrangedoras.

O próprio pensamento de Geertz se envolve na diferença, pois, se assevera ser ele um etnógrafo que escreve sobre etnografia, por outro lado, delata que começou na "filosofia", abandonando-a rapidamente, pois tentava alicerçar seu pensamento mais objetivamente, na variedade do mundo. Seu interesse seria mais empírico do que conceitual, é bem verdade. Contudo, não se apartou dos temas e interesses filosóficos ${ }^{16}$, haja vista sua aproximação de pensadores como Ludwig Wittgenstein, cansado que estava o antropólogo-filósofo de patinar no "gelo flutuante cartesiano, kantiano ou hegeliano".

O "encontro" que é sempre incômodo dá a ler o fio da navalha e a espada em que pesam confrontos etnocêntricos, muitas vezes destrutivos e perversos, os quais, no limite, levam os humanos a todo um malogro: guerra, estupro, invasão, apropriação ilícita, escravização. Coloca o antropólogo, o etnógrafo, o historiador e qualquer um que tenha algo a nos dizer, frente a um "amontoado de escombros ${ }^{17 ", ~-~ i m a g e m ~ q u e ~ r e t o m a ~ A u s c h w i t z, ~ o s ~ c a m p o s ~ d e ~ m o r t i c i ́ n i o, ~ a s ~}$ ditaduras militares, os massacres aos indígenas e camponeses, o esfacelamento de direitos humanos em boa parte do globo, a queda do Muro de Berlim -, signo de um mundo desconcertado ou em processo de desmonte, repleto de identidades irrequietas e voláteis, cujas ligações são imperfeitas, efêmeras e incertas.

O que efetivamente interessa, então? O "encontro", o "lugar" incômodo em que se dá a tensão, os rompimentos e as quebras em um mundo estilhaçado - "devemos examinar os estilhaços $^{18 \prime \prime}$-, que variam ao longo do tempo e do espaço e sofrem com os atravessamentos da psique, dos estados metabólicos do organismo, do amadurecimento intelectual e com os contatos culturais.

Vejamos que o embate cultural é um lugar agônico para o antropólogo, um "encontro incômodo" entre pessoas, ideais, sentidos, culturas, mas é este encontro que o faz "andar", ao

\footnotetext{
${ }^{15}$ GEERTZ, Clifford. Nova luz sobre a antropologia. Tradução: Vera Ribeiro. Rio de Janeiro: Jorge Zahar, 2001, p. 10.

${ }^{16}$ Reparemos no insight de "Nova Luz sobre a antropologia": "toda etnografia tem uma parte que é filosofia, e grande parte do resto é confissão". Ensina Geertz que o sentido não se deita no fabricado, mas é um movimento espiralado do pensamento - eivado de temporalidades disjuntivas e fronteiriças -, que não é nem relativista, nem absolutista, porque, o primeiro inviabilizaria o julgamento, o segundo retiraria o poder da história. Ibid., p. 82.

${ }^{17}$ BENJAMIN, Walter. Magia e técnica, arte e política. Tradução de Sérgio Paulo Rouanet. São Paulo: Brasiliense. 7 ed. 1994, p.226.

${ }^{18}$ GEERTZ, Clifford. Nova luz sobre a antropologia. Tradução: Vera Ribeiro. Rio de Janeiro: Jorge Zahar, 2001, p. 193.
}

Odeere: revista do programa de pós-graduação em Relações Étnicas e Contemporaneidade - UESB. Ano 1, número 1, volume 1, Janeiro - Junho de 2016. 
invés de ficar patinando em lago gelado. É o "encontro", como uma topada, um empurrão, que nos tira da morosidade, da estática e pode nos levar a perambular, passar por lugares e povos, buscando "incessantemente contrastes constantes"19", o que não nos dá qualquer certeza sobre nada - nem sobre o "lugar" do antropólogo -, mas evoca "uma série de posicionamentos", uma névoa de incertezas e nebulosidades.

\section{Passos desajeitados: caminhando por fissuras, brechas, entre lugares}

O corpus: que bela ideia! Sob condição de que se leia no corpus o corpo: quer se procure, no conjunto dos textos retidos para o estudo (e que forma o corpus), não mais somente a estrutura, mas as figuras da enunciação; quer se tenha com esse conjunto alguma relação amorosa (na falta do que o corpus não é mais do que um imaginário científico) $)^{20}$.

Escolhemos como corpus de nosso ensaio, o texto "Usos da diversidade" de Clifford Geertz $^{21}$ e buscaremos lê-lo em seu corpo, ou seja, tentando com ele negociar, fazendo-o dialogar com outros textos, buscando figuras de enunciação e brechas, numa relação erótico-amorosa.

As figuras de enunciação apontam para uma disjunção entre significado e significante, demarcando o ato enunciativo como lugar de produção de sentidos. Nem o enunciado, nem o dentro nem o fora do texto, mas as bordas da inscrição e da observação é que movem o sentido. A que acenamos? Para o fato de que narrativas mestras se desmantelam em histórias divergentes em idiomas e traduções de traduções (na mesma e em outras línguas) absolutamente incoerentes e desconexas. Levar uma história a um cume de verdade, é ato que pretende apagar seu movimento ilusório e falível, mas também conduz ao estereótipo, ao preconceito, ao conflito ressentido, ao etnocentrismo.

Ora, Geertz nos chama a atenção para o fato de que o etnocentrismo não é bom ou ruim em si mesmo, mas que, mesmo com os avanços da globalização e os movimentos humanitários, os graves problemas de discriminação, preconceito e agressão à diferença têm sido a tônica e um empecilho para se lidar com a alteridade.

\footnotetext{
${ }^{19}$ Ibid., p. 10.

${ }^{20}$ BARTHES, Roland. Roland Barthes por Roland Barthes. Tradução: Leyla Perrone-Moisés. São Paulo: Estação Liberdade, 2003, p. 179.

${ }^{21}$ GEERTZ, Clifford. Nova luz sobre a antropologia. Tradução: Vera Ribeiro. Rio de Janeiro: Jorge Zahar, 2001, p. 71.
}

Odeere: revista do programa de pós-graduação em Relações Étnicas e Contemporaneidade - UESB. Ano 1, número 1, volume 1, Janeiro - Junho de 2016. 
No contexto da "reafricanização", o discurso pós-colonial, por exemplo, critica as agruras do imperialismo, mas, por outro lado, caso seja utilizado às avessas, pode servir para o domínio e a opressão do subalterno. Visões etnocentradas, essencialistas e ortodoxas - "africanizar o africano, orientalizar o oriental, ocidentalizar o ocidental, americanizar o americano ${ }^{22 \prime \text {, }}$ "libertando-os" do jugo da mestiçagem, do hibridismo, em busca de uma suposta pureza, podem gestar "guerras de fronteiras", violências e fundamentalismos contra o divergente. Esta atitude dificulta o interesse pelo que está além das fronteiras estabelecidas e desestimula a caminhada em prol de uma Ética da alteridade.

Levado a ultima instância, o etnocentrismo - o privilegiamento de uma dada etnicidade, comumente a ocidental -, pode nos "impedir de descobrir em que tipo de ângulo, nos situamos em relação ao mundo" ${ }^{23}$ e fomentar o que Roger Bastide denominou de "pecado do etnocentrismo ${ }^{24 \prime \prime}$, qual seja, instituir e legitimar uma política de aculturação forçada, de assimilação e de opressão de mentalidades diferentes.

Um suposto consenso universal sobre assuntos normativos parece estar distante, e as culturas não chegarão a opiniões comuns, "pelo menos não tão cedo, ou talvez nunca ${ }^{25 ",}$, sobre o que é decente e o que não o seja, o que é normal e o que deriva da normalidade, o que é positivo e o seu contrário, o que é beleza e o que é grotesco. Saddam Hussein foi condenado por invadir países sem o consentimento das Organizações Unidas - ONU, à cata de petróleo; George W. Bush mesmo tendo invadido o Oriente Médio sem a convalidação da ONU, lançando seu país à guerra cujo pano de fundo era o petróleo, foi reeleito à presidência dos Estados Unidos da América. Alguns veem a postura do jornal francês Charlie Hedbo como simples "direito de expressão", outros como piadas de mau gosto contra líderes islâmicos, passíveis de punição.

Tal complexidade de entendimento exige que evitemos definições e respostas rápidas, sendo de bom tom avisar ao leitor que, melhor se compreende o movimento entre o etnocentrismo e a alteridade, se entrarmos nesta seara com "passos desajeitados", sem tentar apreender o outro e sua complexidade, pois, ao se nos aproximarmos já, o outro "se ausenta sem promessa de retorno e de ressureição ${ }^{26 \prime \prime}$.

\footnotetext{
${ }^{22}$ SAID, Edward W. Cultura e imperialismo. Tradução Denise Bottman. São Paulo: Companhia das Letras, 1995, p. 382.

${ }^{23}$ GEERTZ, op. cit., p. 97.

${ }^{24}$ BASTIDE, Roger. O candomblé da Bahia: rito nagô. São Paulo: Companhia das Letras, 1979, p. 13.

${ }^{25}$ GEERTZ, op. cit., Clifford. p. 82.

${ }^{26}$ LÉVINAS, Emanuel. Humanismo do outro homem. Petrópolis, RJ: Vozes, 2009.
}

Odeere: revista do programa de pós-graduação em Relações Étnicas e Contemporaneidade - UESB. Ano 1, número 1, volume 1, Janeiro - Junho de 2016. 
Em seu livro, "Nova Luz sobre a Antropologia", Clifford Geertz dá como subtítulo "Entrando com passo desajeitado", a capítulo em que discute a pesquisa em Antropologia, seu campo de atuação, as novas teorias em confronto com os pressupostos do estruturalismo. Afirma ser uma das vantagens da antropologia enquanto empreitada acadêmica, o fato de que "ninguém, nem mesmo os que a praticam, sabe exatamente o que ela é". Os antropólogos, quando entram "de mansinho e com passo desajeitado", acabam sendo muito bons, porque "em nossa confusão reside nossa força". Como deve funcionar, pois uma pesquisa, uma leitura e um estudo que se debruce sobre a diversidade e seus usos? Deve primar por elaborar, defender e ampliar uma abordagem social que compreende os "outros", "sem maiúscula e no plural", circulando entre "eles como eles circulam entre si", com o desafio de não ser toda esta incursão dominação por outras vias.

Aberto à alteridade que incomoda, Geertz borra a paisagem transparente e bem orquestrada sobre o que é a cultura ${ }^{27}$ e suas relações com o etnocentrismo. A primeira é uma trama da linguagem, matéria com a qual lida o etnógrafo. Não é apenas o campo da comunicação ou da expressão de sentidos, mas um movimento incessante de écriture ${ }^{28}$, que a abarca em si e a ultrapassa. O segundo são "mônadas semânticas, quase sem janelas". Esse entendimento acerca do etnocentrismo valeu a Geertz uma réplica de Richard Rorty. Para este, a cultura liberal burguesa não é uma mônada etnocentrada. Ao contrário, seria uma cultura orgulhosa em instalar constantemente novas janelas e alargar conexões e fronteiras, haja vista que sua fundamentação é a da "tolerância frente à diversidade 29 ".

No embate Geertz-Rorty, o importante não é a nossa tomada de partido por qualquer uma das posições, mas manter a tensão e o estado de alerta no incômodo encontro das subjetividades que variam. O fato é que, os interesses liberais de Rorty, ao se movimentarem e abrirem suas janelas, também causam constrangimentos e disputas. Por exemplo, convencer países contrários ao aborto, que viabilizem métodos contraceptivos ou abortivos às mulheres vítimas do zika vírus, foi um tema com o qual, recentemente a ONU se debateu sofrendo críticas de todos os lados.

Como abrir "janelas" liberais em países que se recrudescem contrários à educação sexual integral, à saúde sexual e reprodutiva, ao direito da mulher de decidir sobre seu corpo, amparados

\footnotetext{
${ }^{27}$ Cf. DERRIDA, Jacques. Posições. Belo Horizonte: Autêntica, 2001, p. 29.

${ }^{28}$ Ibid., p.65.

29 RORTY, Richard. Acerca do etnocentrismo: uma réplica a Clifford Geertz. In: RORTY, Richard. Objetivismo, relativismo e verdade: escritos filosóficos I. Rio de Janeiro: Relume Dumará, 1997, p. 272.
}

Odeere: revista do programa de pós-graduação em Relações Étnicas e Contemporaneidade - UESB. Ano 1, número 1, volume 1, Janeiro - Junho de 2016. 
em uma legislação alinhada com a homofobia e a misoginia? Não há rede, água de coco e brisa do mar onde tais relações possam, pelo menos por enquanto, se divisar.

Geertz tem consciência destas questões. Tanto que, sua etnografia não pacifica nada, mas busca "manter o mundo em desequilíbrio, puxando tapetes, virando mesas e soltando rojões". Não tranquiliza e não leva o pensamento a pairar em águas calmas. Esta "é tarefa de outros; a nossa é inquietar ${ }^{30 \prime \prime}$.

Inquietar e manter a tensão entre os grupos, os pensamentos, as pessoas borrando os limites entre realidade e representação: "talvez venhamos a considerar que a reconstrução política da Ásia e da África contribuiu mais para transformar a visão de identidade social da Europa e América do que o inverso ${ }^{31 "}$.

Que movimento é este? Trata-se do questionamento da ação etnocêntrica que evoca a cultura em termos de uma totalidade, autônoma e autossuficiente. Pressupõe dissolver as gorduras de uma linguagem supostamente natural, "isto é, da linguagem que finge ignorar que é linguagem ${ }^{32 \prime \prime}$, denunciando a negação da complexidade dos objetos e das culturas e a tentativa de imobilizar a fluidez das identidades dos sujeitos e seu porvir.

Assim, abre espaços para a diferença que faz diferença - talvez a questão seja, o que a diferença nos ensina com a diferença? -, a qual tem que ser reconhecida de modo franco e urgente, não como negação da semelhança, mas abarcando-a, situando-a, concretizando-a. Deste movimento sem clausuras, irrompem identidades como unidades moventes de sentido, produzidas a partir das diferenças.

Já a "mônada semântica" etnocêntrica e reducionista, o discurso - ocidental, religioso de matriz judaico-cristã, paternalista, ou qualquer outro -, engendra estereótipos oportunistas, os quais tentam "comandar" uma instituição, um direito, uma situação, um mito, um discurso, um povo, uma cultura. E o faz tão bem que parece ser "natural" a relação hierárquica entre regenteregido. Tal hierarquia assimétrica forneceu durante muito tempo, a justificativa necessária para a promoção de processos de homogeneização, com vistas a reduzir e inferiorizar o outro, massificando-o, apagando as diferenças dentro da própria diferença e mais ainda, congelando-o num lugar de uma ausência e de uma falta, impondo-lhe a marginalidade e a invisibilidade.

\footnotetext{
${ }^{30}$ GEERTZ, Clifford. Nova luz sobre a antropologia. Tradução: Vera Ribeiro. Rio de Janeiro: Jorge Zahar, 2001, p. 65.

${ }^{31}$ Ibid., p. 220.

32 BARTHES, Roland. O rumor da língua. São Paulo: Martins Fontes, 2004, p. 394.
} 
O etnocentrismo segrega e exclui - utilizando-se de uma trama ideológica e de uma consciência dominante que diferencia grupos, objetificando-os com expressões classificatórias e maniqueístas -, implantando relações de poder sobre o sentido daquilo que o outro "é". Suas raízes remontam a discursos universalistas, como por exemplo, os de matriz judaico-cristã, com seus estabelecimentos da Verdade, Pecado e Salvação. Sua ação não é saudável porque não chama a atenção para a arbitrariedade em que está envolvido e, ao invés disso, tenta fazer-se passar por uma essência autogeradora apagando sua própria condição relativa, contingencial e artificial.

Como nos ensina Silviano Santiago ${ }^{33}$, no caso dos indígenas, o processo de catequese durante os quinhentos, não os acometeu apenas de uma "conversão" e de uma "salvação", mas Ihes impingiu a necessidade de lutar por algo que não fazia parte de seus interesses, posicionandoos entre a Reforma e a Contra-Reforma, introjetando-Ihes uma situação sócio-política e econômica que não Ihes dizia respeito. Com o tempo, isto pode ganhar ares de normalidade, naturalidade, essência e logo, o indígena se vê brigando com os seus costumes, contra seus pajés e mitos, em favor da unidade da Igreja de Roma e do fortalecimento do Estado europeu e da família tradicional burguesa.

Laura de Melo Souza, estudando relações entre feitiçaria e religiosidade no Brasil colônia, aponta que,

o culto dos negros foi simples e puramente confundido com a feitiçaria e como esta era proibida em Portugal, as ordenações reais que contra ela eram dirigidas foram aplicadas no Brasil contra as reuniões de negros que tinham aos olhos dos cristãos algo de demoníaco ${ }^{34}$.

O etnocentrismo promoveu, historicamente, um genocídio cultural, um "semiocidio 35 ", demonizando o discurso do outro, barbarizando cosmogonias, rituais e símbolos culturais. Todos estes saberes serviram para assegurar a dominação colonial do Ocidente, do branco, do homem das classes privilegiadas sobre outras culturas, etnias, grupos sociais, sexualidades não heternormativas.

\footnotetext{
${ }^{33}$ SANTIAGO, Silviano. Vale quanto pesa: ensaios sobre questões político-culturais. Rio de Janeiro: Paz e Terra, 1982, p. 14.

${ }^{34}$ MELO e SOUZA, Laura de. O diabo e a Terra de Santa Cruz: feitiçaria e religiosidade popular no Brasil Colonial. São Paulo: Companhia das Letras, 2000, p.68.

${ }^{35}$ SODRÉ, Muniz. A verdade seduzida. Rio de Janeiro: DP\&A, 2005, p. 7.
}

Odeere: revista do programa de pós-graduação em Relações Étnicas e Contemporaneidade - UESB. Ano 1, número 1, volume 1, Janeiro - Junho de 2016. 
Em pleno século XXI, mesmo com toda a caminhada em prol do reconhecimento das diversidades - de sexo, religião, raça e etnia, nacionalismos -, além do engrossamento dos estudos antropológicos e culturais no Brasil e no mundo, novas visões científicas e filosóficas, como a mecânica quântica e a descrença na noção de verdade sustentada epistemologicamente, alguns segmentos sociais ainda não perceberam que diferenças étnicas e culturais são características da condição humana. Por isso, continuam sendo observados com frequência, mesmo após nosso ingresso no século XXI, casos de agressão contra as religiões afro-brasileiras ${ }^{36}$, e a força com que se fazem presentes, missões evangélicas em áreas indígenas em todo o Brasil e, mais precisamente na região do Oiapoque (Galibi-Marworno, Karipuna, Palikur do Brasil e de Saint-Goerges de l'Oyapoc), na fronteira do Brasil com a Guiana Francesa, e na reserva do Tumucumaque (Wayana-Aparai), no Pará, próximo à fronteira com o Suriname ${ }^{37}$.

É como se não tivessem compreendido a necessidade de pôr em prática a dialética da alteridade, o exercício concreto da identidade na diferença, e de perceber o outro como um possível e concreto no mundo, com suas crenças, valores e sentidos. O outro ainda é um anacronismo em que impera a "colonialidade, ou seja, a dominação de caráter cultural, que nega igualdade ao diferente $^{38 \prime \prime}$ (SODRÉ, 2012, p.42). Por isso, a necessidade de negá-lo, silenciá-lo, demonizá-lo, forçando-o a aceitar a "doxa triunfante, o pensamento único, o consenso fabricado, que fecham o campo de significação, restringem as alternativas, apagam a memória, negam o passado, reificam o presente e sequestram o futuro ${ }^{39 \prime \prime}$.

A mídia também tem contribuído para o pensamento único, através de uma ausência concreta da diversidade, às vezes total e absoluta, ou, de forma mais ardilosa, através da presença apagada, presença que se estrutura em representações pejorativas, negativas, clicherizadas, estereotipadas, estigmatizadas, composta de toda sorte de traços discriminatórios. No caso brasileiro, muitos são os grupos sociais e populações que têm sido anulados ou negativamente representados. Novamente, a população afro-brasileira e os indígenas são os grupos sociais que mais têm sido vítima de tais representações.

Contudo, não devemos ver aí uma relação hierárquica apenas, uma relação fixa entre dominante/dominado, opressor/oprimido. Os estudos pós-coloniais apontam para um "lugar

\footnotetext{
${ }^{36}$ SILVA, Vagner Gonçalves da. Neopentecostalismo e religiões afro-brasileiras: Significados do ataque aos símbolos da herança religiosa africana no Brasil contemporâneo. Mana, Rio de Janeiro, v. 13, n. 1, Apr. 2007.

${ }^{37}$ Cf. http://www.equiponaya.com.ar/religion/XJornadas/pdf/6/6-Almeida.PDF

${ }^{38}$ SODRÉ, Muniz. Reinventando a educação: Diversidade, descolonização e rede. Petrópolis, RJ: Vozes, 2012.

39 SILVA, Tomaz Tadeu da. O currículo como fetiche: a poética e a política do texto curricular. Belo Horizonte: Autêntica, 2003.
}

Odeere: revista do programa de pós-graduação em Relações Étnicas e Contemporaneidade - UESB. Ano 1, número 1, volume 1, Janeiro - Junho de 2016. 
fronteiriço", um "espaço de negociação" de identidades, um interstício, um descentramento, no qual o sujeito constrói-se e é construído, compreende e não censura, interpreta e não ordena, abandona o solilóquio em favor do diálogo no embate com um discurso supostamente hegemônico.

\title{
III. Entre teias, entre-lugares, entre diversidades: correr, viajar, novos ares
}

\author{
Tudo era variegado, poroso, entrelaçado, disperso; a busca da \\ totalidade era um guia incerto, e o sentimento de uma \\ compreensão definitiva era inatingível. \\ Clifford Geertz ${ }^{40}$
}

Nossas reflexões colocam sob suspeita a Metafísica e a Ordem. Levam-nos a uma perspectiva teórica que, por um lado, parte do hibridismo cultural e histórico do mundo póscolonial e, por outro lado, não se opõe a nada. Solicitam uma leitura pós-estruturalista que compreende embates culturais, explicitamente como locais em que culturas se fazem saber/poder - no plural, com um "s" marcado, borrado e dissonante, capaz de produzir um número não finito de efeitos semânticos, sem se deixar reconduzir a um presente simples, e sem qualquer substantivo.

Logo, não há que se falar em completude, certeza e totalidade quando tal pensamento nos convida a analisar a estrutura dos discursos e as formas pelas quais produzem efeitos de sentido entrelaçados, experimentando novos modos de pensar a diferença, os limites e os embates acerca das culturas, o que se assemelha "mais a entender um provérbio, captar uma alusão, perceber uma piada, do que alcançar uma comunhão ${ }^{41 \prime \prime}$.

Afastando-nos de categorias binárias e opositoras, transitando bem ao largo do delírio maniqueísta do Ocidente, fortemente problematizando de que lugar discursivo questões de cultura, identidade, nação são promovidas e institucionalizadas e de que modo são capazes de criar processos de subjetivação, "os usos da diversidade" devem ser lidos como teias semióticas ${ }^{42}$ da própria cultura. Teias entretecidas no encontro de signos que se movimentam, encontram-se e se desencontram, aproximam-se e se distanciam; cada um desses signos deixando uma marca no outro, originando uma identidade e uma diferença, arrastando sentidos, marcando um rasto,

\footnotetext{
${ }^{40}$ GEERTZ, Clifford. Nova luz sobre a antropologia. Tradução: Vera Ribeiro. Rio de Janeiro: Jorge Zahar, 2001, p. 218.

${ }^{41}$ GEERTZ, Clifford. Local Knowledge. New York: Basic Books, 1983, p. 70.

42 GEERTZ, Clifford. A interpretação das culturas. Tradução: Gilberto Velho. Rio de Janeiro: LTC, 1989.
} 
possibilitando o jogo das diferenças, o acontecimento sem local, sem medida, sem tempo, que articula o encontro do "eu" e do "outro", do dentro e do fora.

O que estamos a inferir é que os "usos da diversidade" produzem uma cultura e sua semiótica e, por ela são produzidos, atuando como discursos políticos e pedagógicos. Eles são performáticos, são construtos, ou seja, não originados de uma imanência ou metafísica sem fundo.

Como se sabe, todo texto só faz sentido dentro de jogos de linguagem, por meio do contato entre comunidades discursivas, sistemas de referência e formas díspares de construir o mundo. O sentido emerge de um contexto em interação concreta, ou seja, é temporal e interessado, histórico e resultado de embates e lutas, atravessado por acontecimentos. Qual a questão que se impõem à cultura e aos usos da diversidade? Parafraseando Geertz, as crenças de outros grupos poderiam ser facilmente por nós adotadas caso houvéssemos nascido num lugar ou época diferentes daqueles em que estamos.

Por que não o fazemos? Por que prosseguir agindo como "o Um que se resguarda do outro $^{43}$ "? Esta atitude de indiferença constrange o outro fora de si, mantem a ilusão de uma unicidade interna que não existe, descarta os atravessamentos de seu próprio inconsciente, nega a alteridade e a diferença, tornando-se a pura violência etnocêntrica.

Instados no século XXI, mesmo com todo o arrojo tecnológico da internet e seus cabos de fibra óptica, a despeito de termos mais de 5.000 satélites circundando o planeta, muros (reais e simbólicos) são construídos para separar países e evitar a chegada de estrangeiros. Se por um lado, é verdade que podemos ser transportados de um ponto a outro, de norte a sul, por meio de aeronaves que encurtam as distâncias, se a comunicação se desloca (supostamente livre) até o outro lado do planeta em um click, por outro lado, ao analisarmos o cenário contemporâneo, colocamos sob suspeita nossa capacidade de viver na diversidade e na diferença, haja vista que ainda prosseguimos impondo a cultura hegemônica sobre as populações menos favorecidas, numa violência que tenta eliminar o diferente.

Movimentos reacionários se estendem pelo planeta, do Brasil à Alemanha, dos Estados Unidos ao Qatar, de Cuiabá à Sttutgart, de Nova lorque a Doha, e nos fazem retomar por um lado, a banalidade do mal e por outro, a urgência de atentar para a interculturalidade e para a paz.

\footnotetext{
43 DERRIDA, Jacques. Mal de arquivo: uma impressão freudiana. Tradução: Claudia de Moraes Rego. Rio de Janeiro: Relume Dumará, 2001, p. 100.
}

Odeere: revista do programa de pós-graduação em Relações Étnicas e Contemporaneidade - UESB. Ano 1, número 1, volume 1, Janeiro - Junho de 2016. 
Superando o temor e o ódio à diferença, supera-se também um racismo cognitivo que desperdiça experiências e conhecimentos. Ao tratar a diferença como uma ameaça, ignora-se que é na diversidade que aprendemos. Há entradas cognitivas diversas, legados africanos, indígenas, campesinos, hindus, que são desperdiçados a um alto custo epistêmico e psíquico. A diferença para além do que tem de dessemelhança - é a possibilidade de aprender fora de gramáticas universais e de linguagens algorítmicas.

Para o crítico literário Fredric Jamenson, a globalização, sinônimo de estadunização do mundo, tem se tornado uma estratégia por meio da qual, "Tio Sam" estende seus poderes sobre o globo e tenta fazer passar os seus interesses por universais. A padronização cultural mundial, a aniquilação de culturas populares e tradicionais locais, pauta desta globalização perversa, estrutura-se no terceiro estágio da globalização em que três pontos se sobressaem "armas nucleares somente para os Estados Unidos; direitos humanos e democracia ao estilo americano; e (não tão abertamente) limites à migração e ao fluxo livre da mão-de-obra ${ }^{44 "}$.

Podemos continuar a viver - estamos pensando em agências plurais e identidades plásticas e moventes - com um uso tão restritivo da diversidade? Ora, se é no encontro incomodo de subjetividades que o antropólogo define seu lugar, urge correr e viajar - e não patinar no lago gelado -, especialmente num tempo em que a pasteurização etnocêntrica pretende dar as cartas.

Estudos sobre o orientalismo produzidos por Edward Said, Noam Chomsky e Octavio Paz confirmam que a violência do Vietnam, as agruras na Palestina e a divisão da Índia e do continente africano, o exercício de bombas, as espionagens, a corrupção e uma série de "silogismos

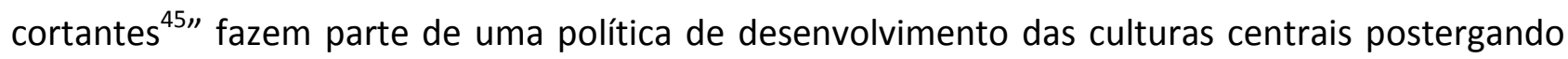
aos combatidos a destruição, um cabedal de doenças, misérias e vidas perdidas.

Os silogismos são o progresso, a revolução, o desenvolvimento que, em lugar da estabilidade fruto da fé na Ciência e no Progresso, resultaram em destruição e morte, caos e frustração. O relativismo, o imediatismo, a fragmentação, o consumo exacerbado, o consumo de demanda, a lógica mercadológica, segundo a qual, os capitalistas do mundo se uniram, a exaltação do corpo produzido nas academias de ginástica, recortado a bisturi e procedimentos cirúrgicos para encher seios, pernas, nádegas ou lipoaspirar gorduras são personagens deste tempo. A

\footnotetext{
44 JAMENSON, Fredric. Globalização e estratégia política. In: Contracorrente. SADER, Emir (Org.). Tradução: Maria Alice Máximo. Rio de Janeiro: Record, 2001, p. 135.

${ }^{45}$ PAZ, Octávio. Vislumbres da Índia. Tradução: Olga Savary. São Paulo: Mandarim, 1996, p. 31.
}

Odeere: revista do programa de pós-graduação em Relações Étnicas e Contemporaneidade - UESB. Ano 1, número 1, volume 1, Janeiro - Junho de 2016. 
"união dos capitalistas" promoveu a exclusão: "o capitalismo, em si, não tem objetivos sociais ${ }^{46 ”}$. O fortalecimento do capital e o desenvolvimento tecnológico, ao invés de gerarem qualidade de vida, tornaram insustentáveis as políticas de pleno emprego.

O progresso da ciência não coincidiu com o progresso da humanidade, o que quer que isso signifique. A corrida desenvolvimentista, a aparentemente irresistível proliferação de técnicas e máquinas, tornou-se capaz de disseminar até mesmo o fim da Humanidade, ameaçando a existência de nações inteiras e, supostamente, de toda a espécie humana. Por outro lado, o nacionalismo e o nativismo vão de uma coerção a outra. Países como a Argélia e o Quênia, historicamente tendo resistido ao imperialismo, cedem espaço "a um Estado com partido único, com regime ditatorial e, no caso argelino, uma oposição islâmica fundamentalista dogmática ${ }^{47 \prime \prime}$.

O "idealismo neurótico" do modernismo desaguou em desilusão: nunca a violência, a iniquidade, a exclusão, a fome, e, portanto, a opressão econômica afetou tantos seres humanos na história da Terra e da humanidade; "a razão instrumental, a onipotência da técnica e o 'todo econômico' não mais funcionam como mitos fundadores ou como metas a serem atingidas ${ }^{48 \prime \prime}$.

Muito se há ainda a falar sobre o "lugar" do antropólogo e os usos da diversidade. Especialmente se sua identidade for encarada de modo ambivalente, decolonial, insurgente. Uma identidade fixa é um estorvo para quem queira "andar" como Geertz.

É preciso se livrar de identidades pesadas e etnocentradas, sair em campo aberto assumindo seus espaços entre tantas outras identidades, numa saudável postura de quem encara a si mesmo e aos outros de vários ângulos, tanto quanto há uma complexa aquarela de possibilidades humanas.

Ao correr, viajar, andar, ares novos fazem ventilar no corpo a mensagem de Geertz: “O estrangeiro não começa à beira-mar, mas na própria pele ${ }^{49}$ ". E a ela não se reduz como uma síntese de compreensão, mas dá-se a ver uma trama generosa e pluralista do mundo, em que entender não nos liberta, não esgota, não desvela absolutamente nada.

\footnotetext{
${ }^{46}$ JAMENSON, op. cit., p. 149.

${ }^{47}$ SAID, Edward W. Cultura e imperialismo. Tradução Denise Bottman. São Paulo: Companhia das Letras, 1995, p. 289.

${ }^{48}$ MAFFESOLI, Michel. O ritmo da vida: variações sobre o imaginário pós-moderno. Tradução: de Clóvis Marques. Rio de Janeiro:Record, 2007, p. 23.

${ }^{49}$ GEERTZ, Clifford. Nova luz sobre a antropologia. Tradução: Vera Ribeiro. Rio de Janeiro: Jorge Zahar, 2001, p. 121.
}

Odeere: revista do programa de pós-graduação em Relações Étnicas e Contemporaneidade - UESB. Ano 1, número 1, volume 1, Janeiro - Junho de 2016. 


\section{Referências}

BARTHES, Roland. O rumor da língua. São Paulo: Martins Fontes, 2004. - Roland Barthes por Roland Barthes. Tradução: Leyla Perrone-Moisés. São Paulo: Estação

Liberdade, 2003.

BASTIDE, Roger. O candomblé da Bahia: rito nagô. São Paulo: Companhia das Letras, 1979.

BENJAMIN, Walter. Magia e técnica, arte e política. Tradução de Sérgio Paulo Rouanet. São Paulo: Brasiliense. 7 ed. 1994.

DERRIDA, Jacques. Mal de arquivo: uma impressão freudiana. Tradução: Claudia de Moraes Rego. Rio de Janeiro: Relume Dumará, 2001. . Papel-máquina. Tradução: Evando Nascimento. São Paulo: Estação Liberdade, 2004. . Posições. Belo Horizonte: Autêntica, 2001.

GEERTZ, Clifford. A interpretação das culturas. Tradução: Gilberto Velho. Rio de Janeiro: LTC, 1989. . Local Knowledge. New York: Basic Books, 1983. . Nova luz sobre a antropologia. Tradução: Vera Ribeiro. Rio de Janeiro: Jorge Zahar, 2001. . Os usos da diversidade. Horizontes Antropológicos, Porto Alegre, ano 5, n. 10, p. 13-34, maio 1999.

JAMENSON, Fredric. Globalização e estratégia política. In: Contracorrente. SADER, Emir (Org.). Tradução: Maria Alice Máximo. Rio de Janeiro: Record, 2001.

LÉVINAS, Emanuel. Humanismo do outro homem. Petrópolis, RJ: Vozes, 2009.

MAFFESOLI, Michel. O ritmo da vida: variações sobre o imaginário pós-moderno. Tradução: de Clóvis Marques. Rio de Janeiro: Record, 2007.

MELO e SOUZA, Laura de. O diabo e a Terra de Santa Cruz: feitiçaria e religiosidade popular no Brasil Colonial. São Paulo: Companhia das Letras, 2000.

MIGNOLO, Walter. Histórias locais/Projetos globais. Colonialidade, saberes subalternos e pensamento liminar. Belo Horizonte: Ed. UFMG, 2003.

OJO-ADE, Femi. Negro: Raça e Cultura. Salvador, BA, Ed. UFBA, 2007, p.5; VELHO, Gilberto. Projeto e Metamorfose: Antropologia das Sociedades Complexas, Rio de Janeiro, Jorge Zahar, 1994.

PAZ, Octávio. Vislumbres da Índia. Tradução: Olga Savary. São Paulo: Mandarim, 1996.

RORTY, Richard. Acerca do etnocentrismo: uma réplica a Clifford Geertz. In: RORTY, Richard. Objetivismo, relativismo e verdade: escritos filosóficos I. Rio de Janeiro: Relume Dumará, 1997.

SAID, Edward W. Cultura e imperialismo. Tradução Denise Bottman. São Paulo: Companhia das Letras, 1995.

Odeere: revista do programa de pós-graduação em Relações Étnicas e Contemporaneidade - UESB. Ano 1, número 1, volume 1, Janeiro - Junho de 2016. 
SANTIAGO, Silviano. Vale quanto pesa: ensaios sobre questões político-culturais. Rio de Janeiro: Paz e Terra, 1982.

SILVA, Tomaz Tadeu da. O currículo como fetiche: a poética e a política do texto curricular. Belo Horizonte: Autêntica, 2003.

SILVA, Vagner Gonçalves da. Neopentecostalismo e religiões afro-brasileiras: Significados do ataque aos símbolos da herança religiosa africana no Brasil contemporâneo. Mana, Rio de Janeiro , v. 13, n. 1, Apr. 2007.

SODRÉ, Muniz. A verdade seduzida. Rio de Janeiro: DP\&A, 2005.

2012.

. Reinventando a educação: Diversidade, descolonização e rede. Petrópolis, RJ: Vozes,

WALSH, Catherine. Pensamiento crítico y matriz (de)colonial. Reflexiones latino-americanas. Quito: Ediciones Abya-yala, 2005.

Alexandre de Oliveira Fernandes: Possui graduação em Letras pela Universidade do Estado da Bahia, pós-graduação em Letras: Língua Portuguesa e Literatura pelas Faculdades Integradas Jacarepaguá/RJ. Também pelas Faculdades Jacarepaguá, cursou pós strictu sensu em Cultura Afrobrasileira. Especialista em Antropologia com Ênfase em Cultura Afro-brasileira pela Universidade do Sudoeste da Bahia - UESB. Professor de Língua Portuguesa e Literatura no Instituto Federal de Educação Tecnológica da Bahia - IFBA/Porto Seguro. Mestre em Letras: Linguagens e Representações pela Universidade Estadual de Santa Cruz / UESC. Doutor em Letras (Ciência da Literatura) pela Universidade Federal do Rio de Janeiro - UFRJ. Desenvolve pesquisas nas áreas de culto aos orixás, mitologia, semiótica, antropologia das religiões, linguística, literatura, leitura e escrita, currículo, educação, pós-estruturalismo, Michael Foucault e Jacques Derrida, Metodologia da Pesquisa, Pesquisa Social, Quali-quantitativa.

Artigo recebido para publicação em: Março de 2016.

Artigo aprovado para publicação em: Maio de 2016.

Odeere: revista do programa de pós-graduação em Relações Étnicas e Contemporaneidade - UESB. Ano 1, número 1, volume 1, Janeiro - Junho de 2016. 